\title{
Engagement of Mexican Millennials at Work in Relation to their Expectations
}

\author{
María Teresa de la Garza Carranza ${ }^{1}$, Eugenio Guzmán Soria ${ }^{1}$, Jorge Armando López Lemus ${ }^{2} \&$ Virginia Susana \\ Soto Hernández ${ }^{1}$ \\ ${ }^{1}$ Instituto Tecnológico de Celaya, México \\ ${ }^{2}$ Universidad de Guanajuato, México \\ Correspondence: María Teresa de la Garza Carranza, Instituto Tecnológico de Celaya, Guanajuato, México.
}

Received: June 3, $2019 \quad$ Accepted: June 25, $2019 \quad$ Online Published: July 18, 2019

doi:10.5539/ibr.v12n8p71 URL: https://doi.org/10.5539/ibr.v12n8p71

\begin{abstract}
The project seeks to find the correlation between retention and labor expectations of the Millennial workforce in Mexico. The study was done with a sample of 422 workers between the ages of 18 and 37, at several types of companies in Mexico, that are experiencing a high rate of staff turnover. The retention and stay-at-work questionnaires were first validated through an exploratory factorial analysis. Subsequently, models were created using the multiple linear regression technique. The results show that work expectations, such as personal and organizational factors are important for staff retention. In addition, our findings are compared with others obtained and a list of recommendations for the development of organizational strategies is proposed as a means of employee retention.
\end{abstract}

Keywords: millennials, work engagement, job expectations, Mexico

\section{JEL: J21, J63, J81}

\section{Introduction}

\subsection{The Millennial Generation}

The work force is an essential element for the development of economic activity in any country. In Mexico, the generation that is currently entering to work force is world known as the Millennial Generation and encompasses those born between 1981 and 2000. This generation has been different from any other due to the technological advance that has been made in the last three decades. These technological advances include electronic communication devices (TV, computers, cell phones, tablets, etc.) and computer development that is related to communication (social networks, online purchases, electronic banking, etc.)

Furthermore, this is a generation that has experienced a relative abundance of resources generally coming from its parents as the Gross Domestic Product (GDP) increases in most countries, but especially in North America (Canada and the United States), as well as in Europe. This phenomenon has also been reported in Latin America, but to a lesser degree. Additionally, this generation is educated under global currents that promote the best use of natural resources, respect for human rights, the integral development of the person, etc.

Although Mexico's Federal Government has made a considerable effort to expand the educational offerings, Mexican Millennials degree of education may vary depending on their economic possibilities and their social environment. In the companies surrounding the Laja-Bajío region these generation is expected to have at a minimum a bachelor's degree or an equivalent as a higher technical college degree. As the hiring expectations are being set by these companies, there is an unprecedented degree of personnel turnover. Due to this high turnover, this research project intends to identify the millennial's expectations from their employees.

\subsection{The Millennial Work Force}

According to North \& Fiske (2015), the work centers are multi-generational. Currently, the workforce has four generations. The silent generation (born between 1925 and 1945), baby boomers (1946-1964). Generation X (1965-1981) and the Millennials (1981-2000). Generation Z (2001-2020) is rapidly approaching to join as workers in the different sectors, at this time because they are not yet of age they are not considered in formal employment, so they are not studied in this investigation. In this sense, Kupperschmidt (2000) defines a 
generation as an identifiable population group that shares years of birth, ages and significant events in its development. The generation of millennials has lived in most societies with relative economic stability, but with a globalized world of uncertainty, terrorism and serious environmental problems. It is also characterized because computer technology was developed along with its chronological growth.

In Mexico, millennials represent approximately a quarter of the Mexican population (almost 30 million), according to data from the National Institute of Statistics and Geography (INEGI, 2011). Page Personnel, a specialized recruitment consultancy firm, identified that this situation poses a new challenge for companies that must recruit them and develop productive and long-term labor relations (Forbes, 2014).

The statistical data of the young people reported by the INEGI (2011) are shown in table 1, where it is verified that the group of the Millennials generation still has a significant challenge in employment. The base taken by the study is the census reported in 2010 where young people between 15 and 29 years old is almost 30 million people. The study is performed based on percentages and it is observed that in each age group there are significant challenges in terms of work and study. Specifically, women are lagging in the work and study categories.

Table 1. Statistical data from Mexico’s young population

\begin{tabular}{llll}
\hline Activity & Total & Men & Women \\
\hline Total & & & \\
Has a job & 47.1 & 63.5 & 31.3 \\
Seeks a job & 3.3 & 4.9 & 1.8 \\
Study & 26.7 & 26.8 & 26.6 \\
Home work & 20.0 & 0.8 & 38.4 \\
Other & 2.4 & 3.4 & 1.5 \\
Not specified & 0.5 & 0.6 & 0.4 \\
15 to 19 years & & & \\
Has a job & 25.8 & 36.6 & 15.0 \\
Seeks a job & 3.0 & 4.6 & 1.3 \\
Study & 54.1 & 53.1 & 55.2 \\
Home work & 13.6 & 1.1 & 26.2 \\
Other & 3.1 & 4.2 & 1.9 \\
Not specified & 0.4 & 0.5 & 0.4 \\
20 to 24 years & & & \\
Has a job & 54.0 & 72.7 & 36.4 \\
Seeks a job & 3.8 & 5.4 & 2.2 \\
Study & 17.5 & 17.6 & 17.3 \\
Home work & 21.9 & 0.6 & 42.2 \\
Other & 2.3 & 3.1 & 1.5 \\
Not specified & 0.5 & 0.6 & 0.4 \\
25 to 29 years & & & \\
Has a job & 65.9 & 88.4 & 45.3 \\
Seeks a job & 3.2 & 4.7 & 1.7 \\
Study & 2.8 & 3.0 & 2.6 \\
Home work & 25.7 & 0.5 & 48.8 \\
Other & 1.8 & 2.6 & 1.1 \\
\hline
\end{tabular}

Source: INEGI, México, un país de jóvenes. Informativo Oportuno, vol. 1, núm. 1, 29 de marzo de 2011.

According to the Page Personnel report (2014) it is mentioned that Millennials have already made their way in companies; in 2013 15\% of all the contracts that the companies made in Mexico were from recent university graduates, almost twice as many as two years ago. In the medium term, it is estimated that this figure will increase by up to $25 \%$, so companies should start adapting their recruitment strategies to the personalities of this generation.

Due to the generational gap in the workforce, the differences between generations have been accentuated more than at any other time (Myers \& Sadaghiani, 2010), and there are certain problems of integrating the millennials into the labor force. The differences are generally attributed to a demanding attitude at work because they want to be taken into account, since they are accustomed to working as a team and their voices heard in all kinds of competitions, even if they do not win (Kaifi, Nafe, Khanfar \& Kaifi, 2012). In many organizations workers "Boomers" are generally in a leadership position and generally treat millennial employees as selfish or lazy (Raines, 2002). On many occasions this influences employee-leader interactions and is reflected in the level of 
dissatisfaction, lack of respect or even distrust.

This level of distrust causes that earning a respectable place within the work environment of the organization is in turn difficult for a millennial. Difficulty in communication openly is related to lack of job satisfaction because communication whether informal or formal may not be enough for these employees (Hatipoglu \& Inelmen, 2018). There are differences also in terms of the length of time and loyalty to their employer, the "Boomers" are used to working between 40 to 60 hours at work and expect younger workers to make merit to obtain promotions. The millennial worker gives a different priority to the work since he prefers to spend time with his family and friends because they have personal interests outside of his work (Afif, 2019).

Arsenault (2004) mentions that organizations will be less competitive globally if they fail to transfer the strengths of generational diversity to the workplace. These general differences create a fertile field for conflicts and barriers resulting in high turnover and a decrease in productivity (Yang \& Guy, 2006). In the same way, several authors agree that managers have a fundamental role in trying to detect how and why differences between generations affect competencies, behaviors, attitudes and other attributes, as well as implementing the best strategies to achieve goals. and objectives achieving a generational merger (Glass, 2007).

Due to globalization and the creation of virtual companies, Millennials have a competitive advantage using information and communication technology. They are also more computer savvy and this puts them on top of more flexible jobs. These means of communication allow Millennials to increase physical limits with social contacts (Fulk \& Collins-Jarvis, 2001). These are advantages that can be used in the workplace as it increases the participation of the group and reduces organizational hierarchies. However, this can also be a source of conflict between generations if the use of technology is not well understood by all generations.

According to Ng, Schweitzer \& Lyons (2010) in a study conducted in Canada with a sample of 23,413 members of the millennial generation, they found that this generation gives great importance to individual aspects of the job and have real expectations about their first job, but they are looking for rapid advancement and the development of new skills. An important aspect is that they seek a meaningful and satisfying life outside of work.

The results of Ng, Schweitzer \& Lyons (2010) suggest the following list of factors to be taken into account in the work by the generation of Millennials. They are presented below in order of importance:

1) Growth opportunities and career advancement

2) Good people to work with

3) Good people to report to

4) Good training opportunities/developing new skills

5) Work-Life balance

6) Good Health and benefits plan

7) Good variety of work

8) Job security

9) Good initial salary level

10) Challenging work

11) Opportunities to have a personal impact

12) Commitment to social responsibility

13) Opportunities to have a social impact

14) Organization is a leader in its field

15) Strong commitment to employee diversity

16) Opportunity to travel

In a study carried out by Calk \& Patrick (2017) they found significant differences between the motivating factors of millennials in the workplace. They concluded that they are more participatory and collaborative than previous generations. Job security is not an important factor for them, since they are willing to change positions in search of better working conditions that satisfy their needs to have free time or a more satisfactory job. This is an important factor to consider by employers for the development of retention strategies.

According to Solnet \& Hood (2008), millennials have associated values such as respect, recognition, openness, 
involvement, continuous development, support management, justice and concern for individuals. Alonso-Almeida \& Llach (2019) found that they are more attracted to companies that are socially responsible. Another characteristic is that this group of workers likes structured work (Chi, Maier \& Gursoy, 2013). In a study conducted by Solnet, Kralj \& Kandampully (2012) found significant differences between the generation of millennials and other workers in terms of: commitment, job satisfaction, organizational citizenship of work, organizational commitment, perceived organizational support, perceived security at work, employability, intention to resign, intention to change positions, recognition and rewards. It is for this reason important to evaluate the difference of the factors of perceived employability of millennial workers.

\subsection{Labor Retention}

When a person leaves his / her position voluntarily or through dismissal, it is considered a movement and implies that the organization has to obtain another resource to fill that work position. The rotation of the employees implies a high cost for the organizations. At the international level, employee turnover is 10.9\% (Forbes, 2018) but may vary according to the type of profession. An average company in the United States loses around \$ 1 million each time 10 executives leave the organization (Ramlall, 2004). The problem of the retention of personnel has multiple variables since it depends as much on the organization as on the personal characteristics and aspirations of the individuals.

Some factors identified by Deery \& Jago (2015) that contribute to staff turnover are: low pay, low skill requirements, excessive hours at work and lack of professional development. These factors contribute to the development of factors such as stress, burnout and, in general, low productivity. Another point of view is the labor-family or family-work conflict (Boyar, Maertz, Pearson \& Keough, 2003). This type of conflict can be especially important in working woman (Batt \& Valcour, 2003). Differences in relation to job satisfaction, job demands and the intention to give up employment also imply cultural factors (Spector, Allen, Poelmans, Lapierre, Cooper et al., 2007).

There are models that have tried to explain why an employee does not stay in the organization. Ramlall (2004) proposes that the main factors to be taken into consideration are: 1) The needs of the employees in terms of their personal requirements and the worker's family role. 2) The work environment where the main part are the people involved in the organization.3) Employee responsibilities can affect the retention; this must be understood in terms of the competencies of the person. 4) Supervision is a factor on which other factors such as staff satisfaction depend and is a decisive factor especially for millennials. 5) Fairness and justice in terms of salary and responsibility; although it can also be in terms of gender equity. 6) The effort must be related to the satisfaction of personal goals of achievement and 7) Development of the worker, the perspective that the employee has based on their personal goals and the opportunities offered by the company. In the Latin-American environment, the studies by Hernández, Restrepo, Conde \& Gómez (2016) suggest similar factors and even Gutiérrez, Carlos Barón \& Rivera (2018) conducted a study in Mexico. A strategy used in these countries is the empowerment of employees as a retention factor (Román-Calderón, Krikorian, Ruiz and Gaviria, 2016).

Some studies have shown that there is a relationship between staff retention and satisfaction (Van Dick, Stellmacher, Ahlswede, Grubba, et al 2004). There are also studies carried out in Mexico in relation to retention factors (Flores-Zambada \& Madero, 2012). However, there are still factors that have not been investigated to determine staff turnover, because the relationship between the factors that intervene in the problem has not been clearly explained (Kyndt, Dochy, Michelsen \& Moayert 2009). To help explain the relationship between the retention of Mexican Millennials in relation to the problem of staff retention, the following hypotheses will be investigated:

H1 There is a correlation between millennials expectations in the work place and their intention to remain in an organization.

\section{Method}

The study is cross-sectional and the questionnaire developed by $\mathrm{Ng}$, Schweitzer \& Lyons (2010) was used as described above to measure expectations at work. The scale used was Likert from 1 to 5 (totally in agreement). To measure retention factors, we used the instrument developed by Kyndt, Dochy, Michielsen \& Moeyaert (2009) with a Likert scale from 1 to 7 . The sample is composed of 422 subjects working in different areas, 258 are men and 164 are women. The data was taken from people working in various organizations in the Celaya and Queretaro region of Mexico. The ages of the interviewees range from 18 to 37, which currently includes the generation of millennials as shown in Table $2.20 \%$ work in the manufacturing industry, $16 \%$ in commerce, $13 \%$ in education, $13 \%$ in the automotive sector, $11 \%$ in the manufacture of food and beverages, $8 \%$ in public functions, $3 \%$ in agriculture and 5\% in other areas. The schooling of the interviewees is as follows: $70 \%$ have a 
baccalaureate level, $24 \%$ have a bachelor's degree, $5 \%$ have a master's degree and less than $1 \%$ have a doctorate. The number of years worked by the population is mostly less than 3 years with $44 \%, 29 \%$ from 4 to 6 years, $15 \%$ from 7 to 9 years, $7 \%$ from 10 to 12 years and the remaining $5 \%$ have more than 12 years old.

Table 2. Range of ages of the subjects

\begin{tabular}{llll}
\hline Age range & Men (1) & Women $(2)$ & Total \\
\hline $18-21$ & 53 & 36 & $22 \%$ \\
$22-25$ & 85 & 50 & $31 \%$ \\
$26-29$ & 62 & 41 & $24 \%$ \\
$30-33$ & 35 & 19 & $13 \%$ \\
$34-37$ & 23 & 18 & $10 \%$ \\
Total & 258 & 164 & $100 \%$ \\
\hline
\end{tabular}

Once the data was gathered, we performed statically procedures to validate the questionnaire and calculate the correlation between the variables as shown next.

\section{Results}

As a first step, the exploratory factor analyzes of the Millennials' expectations questionnaires (Ng, Schweitzer \& Lyons, 2010) and employee retention (Kyndt, Dochy, Michielsen \& Moeyaert, 2009) were carried out. To determine the suitability of the exploratory factor analysis test, the sample adequacy measure KMO (Kaiser, Meyer, Olkin) was calculated, which contrasts if the partial correlations between the variables are sufficiently small. It allows to compare the magnitude of the correlation coefficients observed with the magnitude of the coefficients of the partial correlation. The KMO statistic varies between 0 and 1 . Small values indicate that factor analysis is not adequate (de la Fuente-Fernandez, 2011). In this case, as shown in table 3, the values obtained in the KMO test are close to one. Additionally, Barlett's sphericity test was calculated (table 3) which contrasts the null hypothesis that the correlation matrix is an identity matrix, in which case there would be no significant correlations between the variables and the factorial model would not be relevant. In this case, the significance value of the test is 0.00 which means that the variables are highly correlated to provide a basis for the factorial analysis (Leech, Barrett \& Morgan, 2013).

Table 3. Bartlett and KMO test for the questionnaires

\begin{tabular}{lll}
\hline Indicator & Retention & Expectative \\
\hline Kaiser-Meyer-Olkin measurement & 0.823 & 0.933 \\
Bartlett's test & Aprox. Chi-square 1588.6 & Aprox. Chi-square 3619.8 \\
& g.l. 45 Sig. 0.00 & g.1. 120 Sig. 0.00 \\
\hline
\end{tabular}

As a next step, the explained variance calculation was performed. In the case of the retention questionnaire, two factors were found taking into account that they have eigenvalues greater than 1 . These measurements are an explanation of the variance that helps us to identify the number of factors. When the eigenvalue is less than one, it implies that the factor explains less information than an item could explain. For the first questionnaire (retention), 2 factors were identified and the cumulative variance of the 2 factors is $59.3 \%$. In the case of the second questionnaire (millennial expectations), we also identified 2 factors with an explained variance of 56.7\%. This gives us an acceptable solution to find the factors or latent variables of the applied questionnaire.

To find the factors and the loads associated with the items, the verimax rotation was used. Tables 4 and 5 show the loads of the two questionnaires analyzed. Finally, Cronbach's alpha was calculated for each of the questionnaires and the resulting values for the retention questionnaire was 0.70 and for the expectations of millennials 0.93 . This method allows to estimate the reliability of an instrument through a set of items that are expected to measure the same construct or theoretical dimension. The validity of the instrument refers to the degree to which the instrument measures what it intends to measure. According to George \& Mallery (2013) the coefficient must be above 0.70 to be considered adequate for an instrument. 
Table 4. Loadings of the rotated matrix for the retention questionnaire

\begin{tabular}{|c|c|c|}
\hline Item & $\begin{array}{l}\text { Factors } \\
1\end{array}$ & 2 \\
\hline 10) I love working for this company & 0.875 & \\
\hline 9) The work I'm doing is very important to me & 0.809 & \\
\hline 2) Within this company my work gives me satisfaction & 0.807 & \\
\hline 4) I see a future for myself within this company & 0.807 & \\
\hline 6) If it were up to me, I will definitely be working for this company for the next few years & 0.753 & \\
\hline $\begin{array}{l}\text { 3) If I wanted to do another job or function, I would look first at the possibilities within this } \\
\text { company }\end{array}$ & 0.577 & \\
\hline 8) If I received an attractive job offer from another company, I would take the job & & 0.802 \\
\hline 1) I'm planning on working for another company within a period of three years. & & 0.765 \\
\hline 7)If I could start over again, I would choose to work for another company & & 0.726 \\
\hline 11) I have checked out a job in another company previously & & 0.611 \\
\hline
\end{tabular}

Table 5. Loadings of the rotated matrix for the expectative questionnaire

\begin{tabular}{lll}
\hline \multicolumn{1}{c}{ Items } & Factors \\
& 1 & 2 \\
\hline 6. Good health and benefit plan & 0.785 \\
9. Good initial salary level & 0.677 \\
5 Work-Live balance & 0.674 \\
4 Good training opportunities/developing new skills & 0.669 \\
7. Good variety at work & 0.666 \\
3 Good people to report to & 0.656 \\
4 Job security & 0.642 \\
1 Growth opportunities and career advancement & 0.599 \\
14 Organization is a leader in its field & 0.562 \\
15 Strong commitment to employee diversity & 0.542 \\
2 Good people to work with & 0.541 \\
16 Opportunity to travel & 0.481 \\
12 Commitment to social responsibility & \\
13 Opportunity to have a social impact & \\
13 Opportunities to have a personal impact & \\
10 Challenging work & \\
\hline
\end{tabular}

In the case of the retention questionnaire (table 3), we found two factors associated with the phenomenon. These factors will be identified as 1) Desire to remain in the organization (DR) and 2) Desire to find another organization (DL). For the questionnaire of millennial expectations, the associated factors will be referred to as 1) Organizational factors (MOF) and 2) Personal impact factors (MPF). To test the hypotheses, a bivariate Pearson correlation matrix was performed as shown in Table 6.

Table 6. Bivariate correlations between variables

\begin{tabular}{|c|c|c|c|c|c|c|c|c|c|c|c|}
\hline Variable & Media & $\begin{array}{l}\text { Standard } \\
\text { desviation }\end{array}$ & 1 & 2 & 3 & 4 & 5 & 6 & 7 & 8 & 9 \\
\hline 1.DR & 4.96 & 1.35 & 1 & & & & & & & & \\
\hline 2.DL & 4.71 & 1.43 & $-0.79 * *$ & 1 & & & & & & & \\
\hline 3.MOF & 3.56 & 0.81 & $0.637 * *$ & $-.13 * *$ & 1 & & & & & & \\
\hline 4.MPF & 3.74 & 0.93 & 0.608 & $-.107 *$ & $0.722 * *$ & 1 & & & & & \\
\hline 5.Gender & 1.39 & 0.48 & 0.780 & -.039 & 0.025 & 0.00 & 1 & & & & \\
\hline 6.Age & 25.7 & 4.87 & 0.073 & 0.029 & -.061 & 0.05 & 0.00 & 1 & & & \\
\hline 7.Grade & 1.34 & 0.59 & $0.134 * *$ & -.029 & -0.1 & 0.024 & 0.189 & $0.274 * *$ & 1 & & \\
\hline 8.Tenure & 6.08 & 4.48 & 0.077 & -.01 & -0.03 & .049 & -.095 & $0.753 * *$ & 0.07 & 1 & \\
\hline 9.BusType & 6.55 & 3.8 & 0.00 & 0.00 & -0.081 & -.05 & 0.023 & $0.193 * *$ & 0.038 & $0.168 * *$ & 1 \\
\hline
\end{tabular}

Note. $* *$ Significative $\mathrm{p}<0,01, * \mathrm{p}<0.05$

To complete the analysis, a stepwise regression analysis was performed using the SPSS V software. 23. Two independent variables were analyzed according to those previously found in the factor analysis: desire to remain in the organization or desire to find another organization to work. The results are shown in Table 7. This type of multiple regression analysis only includes those factors that are significant for the model. That is, all the other factors: gender, age, work experience and the type of company where millennials work, do not contribute to explain the retention variables analyzed. 
Table 7. Multiple regression analysis for the study

\begin{tabular}{|c|c|c|c|c|c|}
\hline & $\begin{array}{l}\text { Dependen } \\
\text { (DR). }\end{array}$ & le: Rema & the organization & $\begin{array}{l}\text { Dependent variable: } \\
\text { organization (DL). }\end{array}$ & another \\
\hline \multirow[t]{2}{*}{ Independent variables } & Model 1 & Model 2 & Model 3 & \multirow{2}{*}{\multicolumn{2}{|c|}{$\begin{array}{c}\text { Model 1 } \\
\text { T value }\end{array}$}} \\
\hline & T value & T value & T value & & \\
\hline MOF & 15.05 & 6.98 & 7.18 & \multicolumn{2}{|l|}{-2.86} \\
\hline MPF & & 5.74 & 5.71 & & \\
\hline Grade & & & 3.39 & & \\
\hline $\mathrm{F}$ & 226.68 & 140.13 & 100.07 & \multicolumn{2}{|l|}{8.79} \\
\hline $\mathrm{R}$ & 0.626 & 0.666 & 0.680 & \multicolumn{2}{|l|}{0.151} \\
\hline $\mathrm{R}^{2}$ & 0.392 & 0.444 & 0.457 & \multicolumn{2}{|l|}{0.23} \\
\hline Standard error & 1.049 & 1.00 & 0.99 & \multicolumn{2}{|l|}{1.44} \\
\hline
\end{tabular}

\section{Discussion}

As demonstrated through the regression analysis, there is a relationship between the expectations of millennials and retention variables. With which the work hypothesis is approved. Specifically, for the independent variable remain in the organization the independent variables of organizational factors of the millennials $(t=7.18, p$ $<0.01)$, personal factors of the millennials $(t=5.71, p<0.01)$ and schooling $(t=3.39, p<0.01)$ explain the intention of the workers. For the independent variable to search for another organization, there is a negative relationship between the organizational factors of the millennials $(-2.86, \mathrm{p}<0.01)$. The last regression explains that, if millennial expectations in organizational terms are not met, it is very likely that they will look for another organization to work for. Additionally, we must mention that the variables gender, work experience, age and type of organization are not variables that intervene in the model.

According to Kuron, Lyons, Schwitzer \& Ng (2015), millennials are more susceptible to leave their jobs than other generations because they are even more mobile than any previous generation (Lyons, Schweitzer \& $\mathrm{Ng}$, 2015). The studies conclude that the retention strategies for this generation must be based on economic compensation. Other aspects to consider are feedback and development at work. Schullery (2013) found that there are differences in values between generations and that Millennials are more interested in extrinsic motivators, but also in economic rewards. The above confirms our findings because if organizations are lacking these factors, millennials will be prone to leave their jobs.

The previous analysis gives us information about some of the reasons why Mexican Millennials seek other jobs. They do it when the organizational variables -in terms of their expectations- are not met. This presents companies with the challenge to create strategies to retain their talent because the costs of hiring and terminating employees increases when workers quit their jobs. The retention of human talent in organizations is a factor that affects productivity (Flores-Mendoza, Ardila, Rosas, Lucio \& Colareta, 2018). It is for this reason that personnel departments must develop strategies to prevent organizational desertion and improve the culture and the working environment among the various generations at the work place. Authors such as Chaudhuri \& Ghoshn (2012) have proposed innovative techniques such as "reverse mentoring" where millennials can teach members of other generations their skills. The generation of millennials is a reality at work and HR managers are in the urgency of implementing the best practices to keep them at work (Williams, 2019)

One of the strengths of the present study, is that the sample size is representative of the generation of Millennials and the companies where they work. Another aspect to consider is that there are no studies in Mexico regarding the retention of Millennials at work, and this is a contribution to literature. The weakness of the project is that it is necessary to perform a detailed statistical model through structural equations to help us better understand the phenomenon where values could possibly be included in the workplace because this is a relatively static variable over time (Ralston et al., 2011). Future research can consider factors such as the work-family and family-work relationship, job satisfaction, work life balance and the type of leadership to keep this group engaged at work. In Latin American countries, the new generations entering the workforce represent a challenge socially and at work, due to the low paying conditions that entry level jobs offer to a recent graduate.

\section{References}

Afif, M. R. (2019). Millennials Engagement: Work-Life Balance VS Work-Life Integration. In Social and Humaniora Research Symposium (SoRes 2018). Atlantis Press. https://doi.org/10.2991/sores-18.2019.67

Alonso-Almeida, M. D. M., \& Llach, J. (2019). Socially responsible companies: A re they the best workplace for millennials? A cross-national analysis. Corporate Social Responsibility and Environmental Management, 
26(1), 238-247. https://doi.org/10.1002/csr.1675

Arsenault, P. M. (2004). Validating generational differences: A legitimate diversity and leadership issue. Leadership \& Organization Development Journal, 25(2), 124-141. https://doi.org/10.1108/01437730410521813

Batt, R., \& Valcour, P. M. (2003). Human resources practices as predictors of work-family outcomes and employee turnover. Industrial Relations: A Journal of Economy and Society, 42(2), 189-220. https://doi.org/10.1111/1468-232X.00287

Boyar, S. L., Maertz Jr, C. P., Pearson, A. W., \& Keough, S. (2003). Work-family conflict: A model of linkages between work and family domain variables and turnover intentions. Journal of Managerial Issues, 175-190. https://doi.org/10.1037/e518712013-302

Calk, R., \& Patrick, A. (2017). Millennials through the looking glass: Workplace motivating factors. The Journal of Business Inquiry, 16(2), 131-139.

Chaudhuri, S., \& Ghosh, R. (2012). Reverse mentoring: A social exchange tool for keeping the boomers engaged and millennials committed. Human Resource Development Review, 11(1), 55-76. https://doi.org/10.1177/1534484311417562

Chi, C. G., Maier, T. A., \& Gursoy, D. (2013). Employees' perceptions of younger and older managers by generation and job category. International Journal of Hospitality Management, 34, 42-50. https://doi.org/10.1016/j.ijhm.2013.01.009

De la Fuente-Fernández S. (2011). Componentes principales. Consultado de http://www.fuenterrebollo.com/Economicas/ECONOMETRIA/MULTIVARIANTE/ACP/ACP.pdf

Deery, M., \& Jago, L. (2015). Revisiting talent management, work-life balance and retention strategies. International Journal of Contemporary Hospitality Management, 27(3), 453-472. https://doi.org/10.1108/IJCHM-12-2013-0538

Flores Zambada, R., \& Madero Gómez, S. M. (2012). Factores de la calidad de vida en el trabajo como predictoras de la intención de permanencia. Acta Universitaria, 22(2).

Flores-Mendoza, C., Ardila, R., Rosas, R., Lucio, M. E., Gallegos, M., \& Colareta, N. R. (2018). Intelligence, Latin America, and Human Capital. In Intelligence Measurement and School Performance in Latin America (pp. 79-112). Springer, Cham. https://doi.org/10.1007/978-3-319-89975-6_6

Forbes (2014) Millenials ¿talón de Aquiles de las empresas mexicanas? Retrieved from https://www.forbes.com.mx/millennials-talon-de-aquiles-para-empresas-mexicanas/

Forbes (2018). Las profesiones con mayor rotación laboral. Retrieved from https://www.forbes.com.mx/estas-son-las-profesiones-con-mayor-rotacion-laboral/

Fulk, J., \& Collins-Jarvis, L. (2001). Wired meeting: Technological mediation of organizational gatherings. In F. M. Jablin \& L. L. Putnam (Eds.), The new handbook of organizational communication: Advances in theory, research, and methods (pp. 624-663). Thousand Oaks, CA: Sage Publications.

George, D., \& Mallery, P. (2013). SPSS® for Windows ${ }^{\circledR}$ step by step: A simple guide and reference. Allyn \& Bacon.

Glass, A. (2007). Understanding generational differences for competitive success. Industrial and Commercial Training, 39(2), 98-103. https://doi.org/10.1108/00197850710732424

Gutiérrez, M. F. A., Carlos, V. D. M., Barón, M. C. R., \& Rivera, B. R. G. (2018). Los factores de la rotación de personal en las maquiladoras de exportación de Ensenada, BC. Revista Global de Negocios, 6(2), 25-40.

Hatipoglu, B., \& Inelmen, K. (2018). Demographic diversity in the workplace and its impact on employee voice: the role of trust in the employer. The International Journal of Human Resource Management, 29(5), 970-994. https://doi.org/10.1080/09585192.2017.1322120

Hernández, C. G., Restrepo, I. L., Conde, K. M., \& Gómez, J. M. (2016). Retención de empleados, una estrategia para el éxito de las organizaciones. Revista Fundación Universitaria Luis Amigó (histórico), 3(1), 108-115. https://doi.org/10.21501/23823410.1898

INEGI (2011). México, un país de jóvenes. Informativo Oportuno, 1(1).

Kaifi, B. A., Nafei, W. A., Khanfar, N. M., \& Kaifi, M. M. (2012). A multigenerational workforce: Managing and understanding millennials. International Journal of Business and Management, 7(24), 88-93. 
https://doi.org/10.5539/ijbm.v7n24p88

Kupperschmidt, B. R. (2000). Multigeneration employees: Strategies for effective management. The Health Care Manager, 19(1), 65-76. https://doi.org/10.1097/00126450-200019010-00011

Kuron, L. K., Lyons, S. T., Schweitzer, L., \& Ng, E. S. (2015). Millennials' work values: differences across the school to work transition. Personnel Review, 44(6), 991-1009. https://doi.org/10.1108/PR-01-2014-0024

Kyndt, E., Dochy, F., Michielsen, M., \& Moeyaert, B. (2009). Employee retention: Organisational and personal perspectives. Vocations and Learning, 2(3), 195-215. https://doi.org/10.1007/s12186-009-9024-7

Leech, N., Barrett, K., \& Morgan, G. A. (2013). SPSS for intermediate statistics: Use and interpretation. Routledge. https://doi.org/10.4324/9780203821848

Lyons, S. T., Schweitzer, L., \& Ng, E. S. (2015). How have careers changed? An investigation of changing career patterns across four generations. Journal of Managerial Psychology, 30(1), 8-21.

https://doi.org/10.1108/JMP-07-2014-0210

Myers, K. K., \& Sadaghiani, K. (2010). Millennials in the workplace: A communication perspective on millennials' organizational relationships and performance. Journal of Business and Psychology, 25(2), 225-238. https://doi.org/10.1007/s10869-010-9172-7

Ng, E. S., Schweitzer, L., \& Lyons, S. T. (2010). New generation, great expectations: A field study of the millennial generation. Journal of Business and Psychology, 25(2), 281-292. https://doi.org/10.1007/s10869-010-9159-4

North, M. S., \& Fiske, S. T. (2015). Modern attitudes toward older adults in the aging world: A cross-cultural meta-analysis. Psychological Bulletin, 141(5), 993. https://doi.org/10.1037/a0039469

Page Personnel (2014). Retrieved from https://www.pagepersonnel.com.mx/contenidos/comunicados-de-prensa/reclutar-millennials-el-gran-reto-de -las-compa\%C3\%B1\%C3\%ADas-mexicanas

Raines, C. (2002). Managing millennials. Connecting Generations: The Sourcebook.

Ralston, D. A., Egri, C. P., Reynaud, E., Srinivasan, N., Furrer, O., Brock, D., ... \& Potocan, V. (2011). A twenty-first century assessment of values across the global workforce. Journal of business ethics, 104(1), 1-31. https://doi.org/10.1007/s10551-011-0835-8

Ramlall, S. (2004). A review of employee motivation theories and their implications for employee retention within organizations. Journal of American Academy of Business, 5(1/2), 52-63.

Román-Calderón, J. P., Krikorian, A., Ruiz, C. F., \& Gaviria, A. B. (2016). Apoyo organizacional y empoderamiento como antecedentes de comportamientos empoderados y participación de los empleados. Estudios Gerenciales, 32(139), 154-161. https://doi.org/10.1016/j.estger.2016.03.002

Schullery, N. M. (2013). Workplace engagement and generational differences in values. Business Communication Quarterly, 76(2), 252-265. https://doi.org/10.1177/1080569913476543

Solnet, D., \& Hood, A. (2008). Generation Y as hospitality employees: Framing a research agenda. Journal of Hospitality and Tourism Management, 15(1), 59-68. https://doi.org/10.1375/jhtm.15.1.59

Solnet, D., Kralj, A., \& Kandampully, J. (2012). Generation Y employees: An examination of work attitude differences. Journal of Applied Management and Entrepreneurship, 17(3), 36.

Spector, P. E., Allen, T. D., Poelmans, S. A., Lapierre, L. M., Cooper, C. L., MICHAEL, O. D., ... \& Brough, P. (2007). Cross-national differences in relationships of work demands, job satisfaction, and turnover intentions with work-family conflict. Personnel Psychology, 60(4), 805-835. https://doi.org/10.1111/j.1744-6570.2007.00092.x

Van Dick, R., Christ, O., Stellmacher, J., Wagner, U., Ahlswede, O., Grubba, C., ... \& Tissington, P. A. (2004). Should I stay or should I go? Explaining turnover intentions with organizational identification and job satisfaction. British Journal of Management, 15(4), 351-360. https://doi.org/10.1111/j.1467-8551.2004.00424.x

Williams, G. (2019). Management Millennialism: Designing the New Generation of Employee. Work, Employment and Society. https://doi.org/10.1177/0950017019836891

Yang, S. B., \& Guy, M. E. (2006). GenXers versus boomers: Work motivators and management implications. Public Performance \& Management Review, 29(3), 267-284. 
https://doi.org/10.2753/PMR1530-9576290302

\section{Copyrights}

Copyright for this article is retained by the author(s), with first publication rights granted to the journal.

This is an open-access article distributed under the terms and conditions of the Creative Commons Attribution license (http://creativecommons.org/licenses/by/4.0/). 